\title{
IMPLEMENTASI PENGABDIAN MASYARAKAT BERBASIS ACCESS TO JUSTICE PADA LEMBAGA BANTUAN HUKUM KAMPUS NEGERI PASCA PEMBERLAKUAN UNDANG-UNDANG BANTUAN HUKUM
}

(Community Service Implementation Based on Access to Justice on Legal Aid Institution of State Universities Post-Enactment the Law of Legal Aid)

\author{
Fachrizal Afandi \\ Fakultas Hukum Universitas Brawijaya / \\ Biro Konsultasi dan Bantuan Hukum Fakultas Hukum Universitas Brawijaya \\ Email: fachrizalafandi@gmail.com
}

Naskah diterima: 5 April 2013; revisi: 8 April 2013; disetujui: 10 April 2013

\begin{abstract}
Abstrak
Lembaga Bantuan Hukum Perguruan Tinggi Negeri (LBH PTN) selama beberapa dekade turut mewarnai proses penegakan hukum di Indonesia. Sejak diundangkannya Undang-Undang (UU) Advokat, mewajibkan pemberi bantuan hukum memiliki lisensi kepengacaraan, sehingga LBH PTN tidak bisa lagi leluasa bergerak, meski kemudian terdapat putusan Mahkamah Konstitusi (MK) yang membatalkan pasal pemidanaan dalam UU Advokat tersebut. Secara praktis, posisi LBH PTN harus dipahami sebagai bagian upaya dari para civitas akademika dalam melakukan pengabdian masyarakat dan pengembangan keilmuan hukum. Lahirnya UU No. 16 Tahun 2012 tentang Bantuan Hukum, memberikan angin segar dalam mereposisi LBH PTN dalam melakukan pemberian bantuan hukum yang menjamin akses keadilan. Dengan menggunakan pendekatan sosio legal ditemukan bahwa UU Bantuan Hukum mereposisi peran pengabdian masyarakat LBH PTN setelah vacuum akibat tidak adanya aturan yang jelas dan tegas yang mengakomodir peran mereka selama puluhan tahun bergerak di bidang bantuan hukum pro masyarakat miskin. UU Bantuan Hukum memperluas definisi Pemberi Bantuan Hukum, sehingga memberikan peluang bagi para dosen PTN, paralegal dan mahasiswa hukum yang tergabung dalam LBH untuk melakukan pengabdian masyarakat sekaligus pengembangan keilmuan hukum. Implementasi jaminan access to justice yang dilakukan LBH PTN dapat dilakukan secara lebih optimal pasca diberlakukannya UU Bantuan Hukum. Proses pemberian pelayanan bantuan hukum dapat dilakukan dengan cara melakukan pendampingan secara litigasi maupun non litigasi, dengan bantuan pendanaan dari negara.
\end{abstract}

Kata Kunci: Bantuan Hukum, Lembaga Bantuan Hukum, Perguruan Tinggi Negeri, Pengabdian Masyarakat, Access to Justice

\begin{abstract}
Legal Aid Institution of State Universities (LBH PTN) influence process of law enforcement in Indonesia for several decade. Since the enactment of law on advocate which requires advocate license for legal aid provider, so that LBH PTN could not more move freely, even then there is the Constitutional Court (MK) decision who cancel article punishment in the Advocates ActIn practically, position of $L B H$ PTN should be understood as part of academic community effort to perform community service and legal science development. The enactment of law number 16 year 2012 on legal assistance has given a fresh breeze in repositioning LBH-PTN to do some legal assistance that guaranteed access to justice. By using socio legal approach founded that law on legal assistance has been repositioning the role of community service in LBH-PTN after vacuum caused by the lack of obvious and assertive rules that accommodates their roles for decades to legal assistance which is pro poor society. The expansion of definition legal aid provider in the law on legal aid have been giving an opportunity for state university, paralegals and students who are members of legal aid institution to perform community service together with development of legal science. Implementation of guaranteed access to justice is doing by LBH-PTN could be made optimally post enactment the law on legal aid.Awarding process of legal assistance could be done by accompaniment litigation and non-litigation, dissemination, legal consultation, and other program which related to the implementation of legal assistance with the help of state funds.
\end{abstract}

Keywords: Legal Aid, Legal Aid Institution, State University, Advocate, Access to Justice, Community Service 


\section{A. Pendahuluan}

Undang-Undang Dasar Negara Republik Indonesia Tahun 1945 memberikan mandat pada negara untuk memberikan bantuan bagi setiap warga negara yang mengalami kesulitan mendapatkan akses hukum dan keadilan. ${ }^{1}$ Setiap warga negara memiliki hak untuk mendapatkan bantuan hukum, hak untuk mendapatkan pengakuan, jaminan, perlindungan, dan kepastian hukum yang adil serta perlakuan yang sama di hadapan hukum yang merupakan bagian dari hak konstitusional. ${ }^{2}$

Indonesia sebagai negara hukum yang mengakui dan melindungi serta menjamin hak asasi warga negara terhadap akses pada keadilan (access to justice) dan kesamaan di hadapan hukum (equality before the law) bertanggung jawab menyelenggarakan pemberian bantuan hukum kepada semua masyarakat. Jaminan atas hak konstitusional tersebut belum mendapatkan perhatian secara memadai, sampai lahirnya Undang-undang (UU) No. 16 Tahun 2011 tentang Bantuan Hukum yang menjadi dasar bagi negara untuk menjamin warga negara khususnya bagi orang atau kelompok rentan untuk mendapatkan akses pada keadilan.

Secara konseptual, terdapat dua pengertian Bantuan hukum yakni bantuan hukum dalam arti probono dan bantuan hukum dalam pengertian legal aid. Stakeholders utama pemberian layanan hukum probono adalah advokat, dimana probono menjadi salah satu strategi bagi advokat sebagai profesi terhormat (officium nobille) untuk membela kepentingan umum. Sedangkan konsep legal aid merujuk pada pengertian "state subsidized", pelayanan hukum yang dibiayai atau disubsidi oleh negara. Ide bantuan hukum yang dibiayai negara (publicly funded legal aid) pertama kali ditemukan di Inggris dan Amerika Serikat. ${ }^{3}$ UU Bantuan Hukum yang berlaku di Indonesia menganut konsep Legal Aid dimana pemerintah melalui Kementerian Hukum dan HAM memberikan subsidi biaya kepada penerima bantuan hukum dalam berperkara secara litigasi di peradilan.

UU No. 16 Tahun 2011 tentang Bantuan Hukum memiliki tujuan untuk menjamin dan memenuhi hak bagi Penerima Bantuan Hukum (fakir miskin) untuk mendapatkan akses keadilan, mewujudkan hak konstitusional segala warga negara sesuai dengan prinsip persamaan kedudukan di dalam hukum, menjamin kepastian penyelenggaraan Bantuan Hukum dilaksanakan secara merata di seluruh wilayah Negara Republik Indonesia dan mewujudkan peradilan yang efektif, efisien, dan dapat dipertanggungjawabkan

UU Bantuan hukum mereposisi peran lembaga bantuan hukum kampus sebagai bagian dari civitas akademik untuk dapat melakukan pengabdian masyarakat di bidang hukum berdasarkan keilmuan dan keahlian yang dimiliki. Apalagi lembaga bantuan hukum kampus yang berdiri di Perguruan Tinggi Negeri sebagai bagian dari aparatur Negara memiliki peran penting bagi warga negara yang mencari keadilan, utamanya bagi masyarakat yang tidak mampu untuk memanfaatkan jasa advokat profesional. Keberadaan lembaga bantuan

Pasal 28H ayat (2) UUD NRI 1945 menyatakan bahwa setiap orang berhak mendapat kemudahan dan perlakuan khusus untuk memperoleh kesempatan dan manfaat yang sama guna mencapai persamaan dan keadilan.

Pasal 28 D UUD NRI 1945.

Siti Aminah, Hak Bantuan Hukum Dalam Berbagai Konteks Analisa Terhadap UU No. 16 Tahun 2011 tentang Bantuan Hukum (makalah). 
hukum perguruan tinggi dapat dimaknai sebagai implementasi Tri Dharma perguruan tinggi berupa pengabdian kepada masyarakat.

Undang-undang ini juga seolah menegaskan bahwa yang dimaksud dengan pemberi bantuan hukum tidak terbatas pada Advokat, ${ }^{4}$ namun juga pemberi bantuan hukum lain yaitu dosen dan paralegal yang bernaung di dalam lembaga bantuan hukum kampus, dimana mereka juga diberikan peluang untuk mendampingi perkara hukum yang melibatkan masyarakat tidak mampu. Posisi lembaga bantuan hukum kampus menjadi cukup jelas dalam Undang-undang ini, namun khusus lembaga bantuan hukum kampus negeri terjadi perdebatan mengenai kebolehan pelibatan dosen yang berstatus PNS dalam menangani perkara di peradilan, mengingat adanya larangan bagi PNS untuk menjadi Advokat. ${ }^{5}$

Atas berbagai latar belakang di atas, penulis berkeinginan membahas implementasi pengabdian masyarakat berbasis access tojustice pada lembaga bantuan hukum kampus negeri pasca pemberlakuan UU Bantuan Hukum.

\section{B. Permasalahan}

Ada 2 (dua) permasalahan yang menjadi fokus perhatian penulis berkaitan dengan latar belakang yang telah dikemukakan, yaitu :

1. Bagaimana kedudukan Lembaga Bantuan Hukum Perguruan Tinggi Negeri pasca berlakunya Undang-Undang No. 16 tahun 2011 tentang Bantuan Hukum?
2. Bagaimana implementasi pengabdian masyarakat Lembaga Bantuan Hukum Perguruan Tinggi Negeri yang menjamin access to justice?

\section{Metode Penelitian}

Penelitian ini menggunakan pendekatan sosio legal yaitu pendekatan dengan menggunakan ilmu hukum maupun ilmu-ilmu sosial. ${ }^{6}$ Pendekatan ilmu hukum dilakukan dengan memecahkan problematika hukum secara normatif yang pada dasarnya bertumpu pada penelaahan kritis dan mendalam terhadap bahan-bahan pustaka dan dokumen-dokumen hukum yang relevan dengan permasalahan hukum yang dikaji, dalam penulisan ini digunakan pendekatan peraturan perundangundangan (statute approach). Fokus sekaligus tema sentral penulisan hukum normatif adalah peraturan perundang-undangan, karena yang akan diteliti adalah berbagai aturan hukum. ${ }^{7}$ Pendekatan undang-undang dilakukan dengan menelaah semua undang-undang dan regulasi yang bersangkut paut dengan isu hukum yang sedang ditangani. ${ }^{8}$ Dalam hal ini dilakukan dengan menganalisis ketentuan hukum dalam KUHAP, UU Bantuan Hukum, UU Advokat, dan UU Perguruan Tinggi yang berkaitan posisi Lembaga Bantuan Hukum Perguruan Tinggi Negeri dalam Sistem Peradilan Pidana. Mengingat aturan hukum juga mengandung unsur-unsur etik-moral, tindakan serta nilai-nilai, maka dalam melakukan pemaknaan akan suatu

4 Bandingkan dengan pertimbangan Mahkamah Konstitusi dalam putusan No.06/PUU-II/2004 tanggal 31 Desember 2004, yang membatalkan Pasal 31 UU No. 18 Tahun 2003 tentang Advokat.

$5 \quad$ Lihat Pasal 3 ayat (1) UU No. 18 Tahun 2003 tentang Advokat.

6 Sulistyowati Irianto, Memperkenalkan Kajian Sosio Legal dan Implikasi Metodologisnya (Jakarta: Pustaka Larasan, 2012), hlm. 2.

7 Johnny Ibrahim, Teori dan Metodologi Penelitian Hukum Normatif, (Malang: Bayumedia, 2005), hlm. 302.

8 Peter Mahmud Marzuki, Penelitian Hukum, (Jakarta: Kencana, 2007), hlm. 93. 
aturan selalu terjadi pluralitas dalam konteks sosialnya. Pendekatan ilmu sosial digunakan untuk mengkaji fenomena implementasi bantuan hukum dengan menggunakan metode semiotika hukum, tujuan akhirnya adalah agar fenomena hukum tidak terisolasi dari konteks sosial, budaya dimana hukum itu berada.

\section{Pembahasan}

\section{Kedudukan Lembaga Bantuan Hukum Perguruan Tinggi Negeri}

Sejarah bantuan hukum dapat kita runut mulai dari jaman Romawi, dimana pemberian bantuan hukum didasari sifat kedermawanan (Charity) yang diberikan kepada masyarakat miskin dalam penyelesaian masalah hukum tanpa harus membayar. Dasar pemberian bantuan hukum kemudian menjadi berkembang, bukan hanya karena persoalan belas kasihan namun menjadi hak mendasar bagi setiap warga Negara yang harus dipenuhi agar tidak terjadi diskriminasi. Pemikiran ini berkembang sejak revolusi Perancis dan Amerika yang meyakini ada hubungan antara bantuan hukum dengan kesejahteraan suatu negara. ${ }^{9}$

Hak untuk mendapatkan bantuan hukum dijamin dalam berbagai macam peraturan perundang-undangandilevelnasional. ${ }^{10}$ maupun internasional. ${ }^{11}$ Undang-undang No 39 tahun 1999 tentang Hak Azasi Manusia dan Undangundang No 48 tahun 2009 tentang Kekuasaan Kehakiman menyatakan setiap orang yang tersangkut perkara hukum berhak memperoleh bantuan hukum. Dalam sistem peradilan pidana Indonesia, hak atas bantuan hukum diatur dalam pasal 54 KUHAP dimana guna kepentingan pembelaan diri, Tersangka atau Terdakwa berhak mendapatkan bantuan hukum oleh seseorang atau beberapa orang penasihat hukum pada setiap tingkat pemeriksaan, dan dalam setiap waktu yang diperlukan. Secara lebih spesifik, hak bantuan hukum dinyatakan dalam Pasal 14 (3) d ICCPR yaitu dalam menentukan setiap tuduhan pidana yang ditujukan pada seseorang, setiap orang harus diberi hak untuk mendapatkan bantuan hukum demi kepentingan keadilan, dimana orang tersebut tidak dapat membiayai jasa advokat.

Sejak tahun 1960 an, Perguruan Tinggi khususnya kampus negeri telah memberikan bantuan hukum, dengan mendirikan Lembaga Konsultasi dan Bantuan Hukum. Pada tahun 1963, Fakultas Hukum Universitas Indonesia mendirikan LKBH sebagai pelaksanaan Tri Darma Perguruan Tinggi. Selanjutnya pada tahun 1969, Prof Mochtar Kusumaatmaja, SH menyelenggarakan program bantuan hukum dalam rangka pendidikan hukum adalah melalui pendidikan hukum klinis di biro hukum di Fakultas Hukum Universitas Padjadjaran. LKBH FH Unpad tidak hanya memberikan nasehat hukum, melainkan juga mewakili dan mengadakan pembelaan hukum di muka pengadilan. ${ }^{12}$ Menyusul kemudian pada tahun

9 "Bantuan Hukum: Akses Masyarakat Marjinal terhadap Keadilan" http://www.bantuanhukum.or.id/index. $\mathrm{php} / \mathrm{id} / \mathrm{dokumentasi/penerbitan/231-bantuan-hukum-akses-masyarakat-marjinal-terhadap-keadilan,}$ (diakses tanggal 13 Maret 2013).

10 Lihat Pasal 27 ayat (1), pasal 28 D ayat (1) dan pasal 28 I ayat (1) UUD NRI 1945.

11 Lihat Pasal 7 The Universal Declaration of Human Rights (UDHR) dan pasal 14 ayat (3), pasal 16, pasal 26 International Covenant on Civil and Political Rights (ICCPR).

12 Tim The Indonesian Legal Resource Center dan Forum Solidaritas LKBH Kampus, Menjamin Hak Atas Bantuan Hukum Bagi Masyarakat Marginal Position Paper Ruu Bantuan Hukum Dan Peran Lkbh Kampus (Jakarta: Delapan Cahaya Indonesia Printing, 2010), hlm. 11. 
1972 Fakultas Hukum Universitas Brawijaya melalui Prof. M. Kafrawi, SH selaku Dekan mendirikan Biro Konsultasi dan Bantuan Hukum diilhami oleh model LKBH di FH Unpad dengan struktur organisasi yang dipimpin oleh Dekan secara langsung. ${ }^{13}$

OrganisasiAdvokatpun tidakmau ketinggalan dalam melakukan pemberian bantuan hukum untuk masyarakat miskin, berdasarkan surat keputusan pimpinan Perhimpunan Advokat Indonesia (PERADIN) tanggal 26 Oktober 1970 No.001/Kep/DPP/10/1970 dibentuklah Lembaga Bantuan Hukum (LBH) yang berimbas pada lahirnya berbagai macam LBH di berbagai daerah seperti Yogyakarta, Solo dan menyusul Palembang. Lahirnya LBH-LBH di berbagai kota dan Biro Konsultasi Hukum di Fakultas Hukum mendorong diselenggarakan Konferensi Lembaga Bantuan Hukum dan Biro Konsultasi Hukum se-Indonesia, pada 10-12 Desember 1971. Konferensi tersebut menghasilkan berbagai keputusan penting diantaranya pembentukan Lembaga Bantuan Hukum Tingkat Nasional (National Legal Aid Association) yang merupakan kerjasama antara LBH dan Biro Konsultasi Hukum, menyarankan fakultas hukum di Indonesia menyelenggarakan Biro Konsultasi Hukum untuk masyarakat yang tidak mampu dengan mengikutsertakan para mahasiswa. ${ }^{14}$

Namun pada tahun 1972, dengan alasan keamanan dan ketertiban, pemerintah Orde Baru melalui Instruksi KOMKAMTIB No.TR-173/ KOPKAM/IV/1972 yang ditujukan kepada semua LAKSUS KOPKAMTIBDA, Jepalas Staf Angkatan, Kepala Kepolisian dan Gubernur Kepala Daerah di seluruh Indonesia diperintahkan untuk mencegah pembentukan LBH Daerah kecuali untuk DKI Jakarta. Hal ini berpengaruh pada merosot dan terbatasnya bantuan hukum di Indonesia. ${ }^{15}$

Hal ini kemudian berubah ketika Direktur Jenderal Pembinaan Badan-Badan Peradilan Departemen Kehakiman pada tanggal 12 Oktober 1974 melaluiSuratEdaran No.0466/SekDP/74 menegaskan bahwa larangan Komkabtib tersebut tidak berlaku untuk LKBH Kampus. ${ }^{16}$ Surat Edaran Nomor:0466/Sek-DP/74 mengatur tentang pemberian bantuan hukum oleh Biro Bantuan Hukum Fakultas Hukum Negeri yang isinya termasuk persyaratan pendirian Biro Bantuan Hukum yang dapat memperoleh bantuan/perhatian pihak Pengadilan Tinggi/ Pengadilan Negeri, yaitu antara lain :

a. Biro Bantuan Hukum diberikan dalam rangka satu program pendidikan hukum yang dipersiapkan dengan baik.

b. Bantuan Hukum yang diberikan oleh Mahasiswa Hukum tingkat IV dan V yang turut dalam program bantuan hukum harus diselenggarakan di bawah pengawasan dan bimbingan dosen/tenaga pengajar yang telah berpengalaman dalam soal pembelaan perkara/pengadilan.

c. Biro hanya diperbolehkan membela orang yang kurang mampu tanpa memungut bayaran dan tidak bermaksud menyaingi pengacara yang profesinya membela perkara.

d. Dianjurkan agar ada kerja sama yang baik antara Biro Bantuan Hukum Fakultas dengan para Pengacara/Advokat.

\footnotetext{
13 Imam Ismanu, dkk, Profil Pengabdian Masyarakat BKBH FH UB 2012 (Malang: FH UB, 2013), hlm. 3.

14 Tim The Indonesian Legal Resource Center dan Forum Solidaritas, Op.Cit., hlm. 12.

15 Ibid.

16 Ibid., hlm. 13.
} 
Penerbitan Surat Edaran ini didasarkan pada alasan yaitu pelaksanaan bantuan hukum oleh fakultas hukum mengandung fungsi ganda yaitu pada satu pihak merupakan kegiatan pendidikan dalam artian melatih keterampilan para mahasiswa hukum dalam menghadapi penerapan hukum secara konkret, sedangkan di lain pihak merupakan kegiatan pengabdian masyarakat dalam artian memberikan pelayanan kepada masyarakat sesuai dengan Tri Darma Perguruan Tinggi. Imbas dari Surat Edaran ini adalah Lembaga bantuan hukum perguruan tinggi negeri dapat berpraktik kembali di pengadilan negeri dalam melakukan pembelaan kepada masyarakat yang kurang mampu dengan tujuan untuk menyelenggarakan pendidikan hukum.

Pengaturan prosedur pendirian Biro Bantuan Hukum ini pun disempurnakan dengan adanya Surat Ketua Mahkamah Agung R.I. Nomor : 084/ TUN/VIII/1989 Perihal Mohon petunjuk adanya perbedaan pendapat Pengadilan Jambi dengan Fakultas Hukum Universitas Jambi dalam masalah struktur organisasi dan operasional Biro Bantuan Hukum di Universitas tanggal 14 Agustus 1989 yang pada pokoknya memberikan petunjuk :

1) Pembentukan dan susunan Pengurus Biro Bantuan Hukum Fakultas Hukum Universitas Jambi adalah urusan intern dan terserah kepada Fakultas Hukum itu sendiri;

2) Sedangkan adanya keinginan Fakultas Hukum tersebut untuk mendaftarkan Biro Bantuan Hukumnya pada Pengadilan Tinggi Jambi hendaknya Saudara sambut dengan baik.

3) Tetapi yang boleh berpraktek di muka Pengadilan hanyalah mereka-mereka yang diangkat oleh Menteri Kehakiman (Advokat) dan yang diberi ijin berpraktek oleh Ketua
Pengadilan tinggi (Pengacara Praktek); Berarti hanya mereka-mereka yang telah memenuhi persyaratan-persyaratan seperti tersebut dalam Surat Edaran Mahkamah Agung RI tanggal 25 November 1988 No. 8 Tahun 1988 tentang Petunjuk Pelaksanaan Keputusan Bersama Ketua Mahkamah Agung RI dan Menteri Kehakiman RI tanggal 6 Juli 1987 saja yang dibenarkan menjalankan kegiatan profesi sebagai Penasehat Hukum.

4) Sedang apabila didirikannya Biro Bantuan Hukum semacam itu dimaksudkan untuk membimbing Mahasiswa Hukum tingkat akhir untuk berpraktek hukum di muka Pengadilan maka hal itu dapat terjadi setelah pihak Universitas mengadakan kerja sama dengan Pengadilan Tinggi. Sesuai dengan Surat Mahkamah Agung tanggal 20 Oktober 1987 No. 39/TUN/X/1987 Perihal Persetujuan Kerja sama mengenai Bantuan Hukum maka sebagai pelaksanaan dari kerja sama antara Ketua Pengadilan Tinggi dan fihak Universitas, jumlah dosen pembimbing Mahasiswa Hukum tersebut paling banyak 3 (tiga) orang, kepada mereka itu dapat Saudara beri ijin praktek khusus yang hanya berlaku untuk mendampingi Mahasiswa berpraktek hukum.

Menurut Surat Ketua Mahkamah Agung ini, Lembaga Bantuan Hukum Kampus dapat mendaftarkan lembaganya kepada Pengadilan Tinggi untuk diberikan ijin praktik khusus dengan syarat Universitas tempat lembaga bantuan hukum tersebut bernaung harus memiliki kerja sama dengan Pengadilan Tinggi setempat, dengan tujuan melakukan pengembangan keilmuan hukum.Selama kurun waktu tersebut terlihat LBH Kampus secara sosiologis memiliki peran dalam membangun gerakan bantuan hukum di Indonesia. 
Pada tahun 2003 disaat Undang-Undang No.18 Tahun 2003 tentang Advokat disahkan dan diberlakukan secara perlahan namun pasti LBH Kampus mulai mati suri. Hal ini dikarenakan pengaturan pengertian Advokat yang termuat dalam pasal 1 angka 1 dan 2 UU Advokat memberikan batasan pemberian jasa hukum harus dilakukan oleh Advokat, jasa hukum yang dimaksud meliputi konsultasi hukum, bantuan hukum, menjalankan kuasa, mewakili, mendampingi, membela, dan melakukan tindakan hukum lain untuk kepentingan hukum klien. Di bagian lain terdapat ancaman pidana penjara paling lama 5 (lima) tahun dan denda paling banyak Rp 50.000.000.-dalam Pasal 31 UU Advokat bagi setiap orang yang bukan advokat namun menjalankan pekerjaan profesi advokat berupa pemberian jasa hukum seperti konsultasi hukum, bantuan hukum, menjalankan kuasa, mewakili, mendampingi, membela dan melakukan tindakan hukum lain, untuk kepentingan hukum klien, di dalam maupun diluar pengadilan. Ketentuan kriminalisasi ini menimbulkan keresahan di kalangan pegiat LBH Kampus, karena dengan adanya pasal ini sejumlah dosen yang bekerja atas nama $\mathrm{LBH}$ Kampus dikenakan tuduhan melanggar UU Advokat, yang berakibat LBH Kampus di PTN menjadi mati suri.

Pada tahun 2004, Lembaga Konsultasi dan Pelayanan Hukum (LKPH) Universitas Muhammadiyah Malang (UMM), mengajukan Permohonan Judicial Review (JR) Pasal 31 UU Advokat ke Mahkamah Konstitusi, dimana dalam putusannya dengan nomor Perkara No.006/PUUII/2004 tentang Pengujian Pasal 31 UU Advokat memutuskan bahwa Pasal 31 UU Advokat bertentangan dengan UUD1945 dan menyatakan Pasal 31 UU Advokat tidak mempunyai kekuatan hukum mengikat. Mahkamah
Konstitusi dalam pertimbangannya menyatakan bahwa UUD 1945 Pasal 1 ayat (3) secara tegas menyatakan Indonesia adalah negara hukum yang dengan demikian berarti, bahwa hak untuk mendapatkan bantuan hukum sebagai bagian dari hak asasi manusia,harus dianggap sebagai hak konstitusional warga negara, kedatipun undang-undang dasar tidak secara eksplisit mengatur atau menyatakannya, dan oleh karena itu negara wajib menjamin pemenuhannya. Selain itu, dalam pertimbangannya, MK juga menyatakan bahwa keberadaan pasal tersebut telah membatasi kebebasan seseorang untuk memperoleh sumber informasi hanya pada seorang advokat. Padahal hak atas informasi dijamin dalam pasal 28F UUD 1945, yaitu setiap orang berhak berkomunikasi dan memperoleh informasi untuk mengembangkan pribadi dan lingkungan sosialnya serta berhak mencari dan memperoleh informasi dari segala saluran yang ada. MK menilai pula materi UU Advokat terlalu jauh mengatur hukum acara. Pemikiran bahwa kelak hanya advokat yang boleh beracara di muka pengadilan dinilai MK sebagai materi yang harusnya diatur dalam hukum acara. Sehingga melalui putusan ini, MK menegaskan bahwa Advokat bukan satu-satunya pihak yang boleh beracara di muka pengadilan.

Namun berdasarkan hasil penelitian Indonesian Legal Resource Center (ILRC) pasca putusan MK, masih menemukan LKBH Kampus yang dilarang menjalankan fungsinya untuk memberikan bantuan hukum. Hal ini karena aparat penegak hukum khususnya polisi tidak mengetahui putusan MK bahwa pasal 31 UU Advokat tidak mengikat secara hukum. Mahkamah Agung mencoba mengatasi permasalahan ini melalui surat Sekretaris Mahkamah Agung No 07/SEK/01/1/2007 tanggal 11 Januari 2007 yang menyatakan LBH Kampus 
baik PTN/PTS dapat mewakili masyarakat miskin dalam beracara di pengadilan. ${ }^{17}$

Sebenarnya jika ditelusuri dalam peraturan perundang-undang, advokat melalui organisasi advokat pun memiliki kewajiban untuk melakukan bantuan hukum. Hal ini dapat ditelusuri dalam Undang-Undang No.18 Tahun 2003 tentang Advokat, Peraturan Pemerintah 83 tahun 2008 tentang Persyaratan dan Tata Cara Pemberian Bantuan Hukum Secara CumaCuma dan Peraturan Peradi No 1 tahun 2010 tentang Petunjuk Pelaksanaan Pemberian Bantuan Hukum Secara Cuma Cuma. Meski demikian sifat pemberian bantuan hukum yang diberikan oleh Advokat adalah Pro Bono artinya tidak ada kewajiban bagi mereka untuk melakukan pemberian bantuan hukum. Hal ini menyebabkan dari belasan ribu advokat yang terdaftar di Perhimpunan Advokat Indonesia (Peradi) tidak lebih dari lima puluh Advokat yang teregister di Pusat Bantuan Hukum Peradi yang melaksanakan bantuan hukum secara cuma-cuma. Hal ini disebabkan karena beberapa advokat merasa sudah pernah dulu melakukan, beberapa advokat lain menganggap lebih baik memberikan dananya ke LBH yang fokus pada upaya bantuan hukum cuma-cuma, selain tiadanya upaya paksa dari organisasi advokat yang turut menyebabkan kewajiban memberikan bantuan hukum cuma-cuma tidak bisa ditegakkan. ${ }^{18}$

Peran Lembaga Bantuan Hukum Perguruan Tinggi dalam melakukan pengabdian masyarakat berupa bantuan hukum menjadi sangat penting mengingat fakta di atas, apalagi jika dikaitkan dengan kebutuhan pengembangan dan penyebaran ilmu pengetahuan yang mereka miliki. Pendirian lembaga bantuan hukum di kampus negeri dapat dimaknai sebagai usaha untuk mewujudkan cita-cita negara hukum. Setidaknya dengan diundangkannya Undang-Undang No 16 tahun 2011 tentang Bantuan Hukum, tujuan pemenuhan hak bagi Penerima Bantuan Hukum (fakir miskin) untuk mendapatkan akses keadilan, penjaminan hak konstitusional segala warga negara sesuai dengan prinsip persamaan kedudukan di dalam hukum, penjaminan kepastian penyelenggaraan Bantuan Hukum dilaksanakan secara merata di seluruh wilayah Negara Republik Indonesia dan perwujudan peradilan yang efektif, efisien, dan dapat dipertanggungjawabkan dapat dilaksanakan secara efektif oleh lembaga bantuan hukum. ${ }^{19}$

UU Bantuan hukum seakan juga menegaskan putusan MK dengan nomor Perkara No.006/ PUU-II/2004 tentang definisi Bantuan Hukum dan memberikan definisi yang lebih jelas tentang siapa yang disebut sebagai Pemberi Bantuan Hukum. Bantuan Hukum dalam Pasal 1 jo pasal 2 UU Bantuan Hukum didefinisikan sebagai jasa hukum yang diberikan oleh Pemberi Bantuan Hukum secara cuma-cuma kepada Penerima Bantuan Hukum yaitu orang atau kelompok orang miskin, sedangkan dalam Pasal 1 ayat (3) mendefinisikan Pemberi Bantuan Hukum sebagai Lembaga Bantuan Hukum atau Organisasi Kemasyarakatan yang memenuhi persyaratan sebagaimana diatur dalam pasal 8 ayat (2) dimana Pemberi Bantuan Hukum harus berbadan hukum, terakreditasi berdasarkan

17 Ibid., hlm. 9.

18 "Dipertanyakan, Dedikasi Pengacara Sukses untuk Probono" http://www.hukumonline.com/berita/baca/ It4fa399b190322/dipertanyakan--dedikasi-pengacara-sukses-untuk-probono, (diakses tanggal 27 Maret 2013).

19 Pasal 3 UU Bantuan Hukum. 
Undang-Undang Bantuan Hukum, memiliki kantor atau sekretariat yang tetap, memiliki pengurus, dan memiliki program Bantuan Hukum. ${ }^{20}$

Persyaratan yang dikemukakan dalam UU Bantuan Hukum tersebut, tentunya tidak sulit untuk dipenuhi oleh Lembaga Bantuan Hukum Kampus baik swasta maupun negeri, hal ini dikarenakan secara teknis status badan hukum LBH mengikuti badan hukum Universitas induknya, sudah pasti memiliki pengurus yang terdiri dari civitas akademika, program bantuan hukum yang sudah tertata dan kesekretariatan yang sudah tersedia.

Khusus Lembaga bantuan hukum Perguruan Tinggi Negeri, dengan adanya UU Bantuan Hukum ini dapat mereposisi peran pengabdian masyarakat mereka dalam bentuk bantuan hukum yang pro masyarakat miskin dalam menjamin access to justice. Hal ini disebabkan adanya perluasan definisi Pemberi Bantuan Hukum dalam UU Bantuan Hukum. Tidak hanya Advokat satu-satunya profesi yang boleh memberikan bantuan hukum sebagaimana diatur dalam UU Advokat, namun lembaga bantuan hukum dan organisasi kemasyarakatan juga mendapatkan legalitas untuk turut memberikan bantuan hukum khusus masyarakat tidak mampu.

\section{Implementasi Pengabdian Masyarakat Lembaga Bantuan Hukum Perguruan Tinggi Negeri yang Menjamin Access To Justice}

Undang-Undang No 12 Tahun 2012 tentang Pendidikan Tinggi mengamanatkan civitas akademika di lingkungkan Perguruan
Tinggi melakukan kegiatan tri darma berupa pengajaran, penelitian dan pengabdian kepada masyarakat. Pasal 47 ayat 1 dan 2 UU Pendidikan Tinggi menyatakan bahwa:

(1) Pengabdian kepada Masyarakat merupakan kegiatan Sivitas Akademika dalam mengamalkan dan membudayakan IImu Pengetahuan dan Teknologi untuk memajukan kesejahteraan umum dan mencerdaskan kehidupan bangsa.

(2) Pengabdian kepadaMasyarakatsebagaimana dimaksud pada ayat (1) dilakukan dalam berbagai bentuk kegiatan sesuai dengan budaya akademik, keahlian, dan/atau otonomi keilmuan Sivitas Akademika serta kondisi sosial budaya masyarakat.

Sedangkan dalam Undang-undang No. 14 tahun 2005 tentang Guru dan Dosen, mendefinisikan Dosen sebagai pendidik profesional dan ilmuwan dengan tugas utama mentransformasikan, mengembangkan, dan menyebarluaskan ilmu pengetahuan, teknologi, dan seni melalui pendidikan, penelitian, dan pengabdian kepada masyarakat. ${ }^{21}$ Pasal 60 huruf a UU Guru dan Dosen ditegaskan lagi bahwa dosen memiliki kewajiban profesional berupa melaksanakan pendidikan, penelitian, dan pengabdian kepada masyarakat.

Dosen memiliki beban kerja sebagaimana diatur dalam pasal 72 UU Guru dan Dosen yang mencakup kegiatan pokok yaitu merencanakan pembelajaran, melaksanakan proses pembelajaran, melakukan evaluasi pembelajaran, membimbing dan melatih, melakukan penelitian, melakukan tugas tambahan, serta melakukan pengabdian kepada masyarakat.

\footnotetext{
20 Bandingkan dengan pasal 1 angka 10 RUU KUHAP yang menyatakan bahwa yang dimaksud penasehat hukum adalah advokat atau orang lain yang memberi jasa hukum baik di dalam maupun di luar pengadilan yang memenuhi persyaratan berdasarkan ketentuan Undang-Undang.

21 Pasal 1 angka 2 UU Guru dan Dosen.
} 
Khusus Dosen pegawai negeri sipil yang bernaung di Perguruan Tinggi Negeri selain kedua UU diatas, mereka juga tunduk pada UU No. 8 Tahun 1974 tentang Pokok-Pokok Kepegawaian sebagaimana telah diubah dengan UU No. 43 Tahun 1999 tentang Perubahan Atas UU No. 8 Tahun 1974 tentang Pokok-Pokok Kepegawaian serta PP No. 53 Tahun 2010 tentang Disiplin Pegawai Negeri Sipil, dimana ada larangan bagi Pegawai Negeri Sipil untuk menjadi anggota dan/atau pengurus partai politik, ${ }^{22}$ dilarang tanpa izin Pemerintah menjadi pegawai atau bekerja untuk negara lain dan/ atau lembaga atau organisasi internasional ${ }^{23}$ PNS dilarang bekerja pada perusahaan asing, konsultan asing, atau lembaga swadaya masyarakat asing. ${ }^{24}$ Dosen PNS juga dilarang memberikan jasa hukum dengan berprofesi sebagai Advokat ${ }^{25}$ dan Notaris. ${ }^{26}$

Pengabdian masyarakat yang dilakukan oleh sivitas akademika Fakultas Hukum di Perguruan Tinggi Negeri memiliki banyak bentuk, salah satu yang paling menonjol dan membedakan pengabdian masyarakat yang dilakukan oleh Fakultas Hukum dengan fakultas lainnya adalah dalam bentuk pendirian Lembaga/ Biro Bantuan Hukum. Sebagaimana dilansir oleh The Indonesian Legal Resource Center (ILRC) LBH Fakultas Hukum memiliki kontribusi penting terhadap gerakan bantuan hukum di Indonesia, beberapa alasan yang mendukung argumentasi ini antara lain : terdapat LBH hampir di setiap Fakultas Hukum diseluruh Indonesia termasuk di wilayah terpencil. LBH Fakultas Hukum menjadi tempat bagi mahasiswa untuk mendiskusikan serta menelaah antara teori dan hukum yang hidup di masyarakat, sekaligus juga untuk meningkatkan pengabdian mahasiswa kepada masyarakat; Kehadiran LBH Fakultas Hukum bertitik tolak dari kesadaran serta dedikasi dalam pengabdiannya terhadap masyarakat dalam rangka pelaksanaan suatu Community Oriented Legal Education yaitu realisasi terhadap dharma ketiga dari Tri Dharma Perguruan Tinggi di bidang hukum dan kemanusiaan. ${ }^{27}$

Pemberian bantuan hukum yang dilakukan oleh LBH PTN selain berfungsi sebagai bentuk tridharma perguruan tinggi berupa pengabdian masyarakat, juga memiliki empat fungsi utama sebagaimana dinyatakan oleh Akil Muchtar, Pertama, Proses hukum yang fair dan impartial yang terjadi jika para pihak memiliki posisi dan kekuatan yang seimbang dari sisi pengetahuan dan ketrampilan hukum. Kedua, memperkuat upaya menegakkan keadilan substansial melalui proses hukum yang fair dan impartial. Ketiga, bantuan hukum memberikan ruang interaksi antara para ahli dan profesi hukum dengan masyarakat umum. Keempat, kepatuhan terhadap hukum hanya akan berkembang pada saat masyarakat memahami kedudukan dan materi aturan hukum, sehingga mereka dapat menjalani prosedur hukum dengan baik, atau bahkan mengkritisi materi serta praktik penegakan hukum. ${ }^{28}$ Keempat fungsi inilah yang

Pasal 3 ayat (3) UU No. 43 Tahun 1999.

$23 \quad$ Pasal 4 angka 3 PP No. 53 Tahun 2010.

24 Pasal 4 angka 4 PP No. 53 Tahun 2010.

Pasal 3 ayat 1 UU Advokat.

26 Pasal 3 UU No. 30 Tahun 2004 tentang Jabatan Notaris.

Tim The Indonesian Legal Resource Center dan Forum Solidaritas LKBH Kampus, Op.Cit., hlm. 5.

28 M. Akil Mochtar, "Bantuan Hukum Sebagai Hak Konstitusional Warga Negara" (makalah disampaikan pada "Karya Latihan Bantuan Hukum (KALABAHU)", diselenggarakan oleh Lembaga Bantuan Hukum, Jakarta, 30 Maret 2009). 
kemudian turut berpengaruh pada jaminan access to justice bagi masyarakat miskin.

Jaminan Access to justice atau akses pada keadilan memiliki makna persamaan dengan hak untuk memperoleh, menggunakan dan mendapatkan manfaat dari proses keadilan yang diperoleh melalui pengadilan maupun melalui mekanisme nonformal. Akses disini semestinya memungkinkan masyarakat miskin mendapat jaminan dan pengakuan dalam menggunakan hukum acara dan sarana dalam sistem peradilan untuk mendapatkan keadilan dan kebenaran materiil. Sebagai tambahan, kata akses dapat diartikan sebagai sebuah metode dan prosedur. Upaya memperluas akses masyarakat miskin atas keadilan, tanpa membahas metode dan prosedur pelayanan, pencapaian dan pemenuhannya, bisa berakibat keadilan tidak akan pernah dinikmati oleh masyarakat miskin. ${ }^{29}$ Akses pada keadilan ini semestinya memungkinkan masyarakat miskin mendapat jaminan dan pengakuan dalam menggunakan hukum acara dan sarana dalam sistem peradilan untuk mendapatkan keadilan dan kebenaran materiil. ${ }^{30}$

Sebagai bagian dari hak atas keadilan, Roger Smith sebagaimana dikutip oleh Uli Parulian Sihombing mengidentifikasi sembilan prinsip access to justice, yaitu: ${ }^{31}$

1. Akses keadilan merupakan hak konsitusional setiap warga negara;

2. Kepentingan warga negara harus lebih besar dibandingkan dengan kepentingan penyedia jasa bantuan hukum, dalam menentukan kebijakan yang berkaitan dengan akses keadilan;

3. Tujuannya tidak hanya keadilan prosedural, tetapi juga keadilan substantif;

4. Setiap warga negara membutuhkan bantuan hukum untuk kasus perdata maupun pidana;

5. Akses menuju keadilan mensyaratkan untuk melakukan setiap tindakan untuk mencapai pemenuhan tujuannya termasuk reformasi hukum formil dan materil, pembaruan pendidikan, informasi dan pelayanan hukum;

6. Kebijakan atas pelayanan hukum dengan memperkenalkan bantuan hukum yang dibiayai oleh negara (publicly funded) atau yang disediakan oleh advokat;

7. Keterbatasan sumber daya (resource) atas bantuan hukum bukan merupakan hal yang mengakhiri akses menuju keadilan, tetapi merupakan pembatasan cara pemberian bantuan hukum;

8. Bantuan hukum harus efektif, terlalu banyak persyaratan untuk mendapatkan bantuan hukum hal yang tidak effektif;.

9. Penggunaan teknologi yang potensial membantu bantuan hukum seperti teknologi informasi dll;

Dalam rangka menjamin pemenuhan hak untuk mendapatkan akses keadilan berupa bantuan hukum bagi setiap orang, keberadaan dan peran LBH PTN sebagai pemberi bantuan hukum menjadi sangat penting bagi pencari keadilan, terutama bagi mereka yang tergolong

\footnotetext{
29 Kelompok Kerja Akses terhadap Keadilan Kementerian Negara Perencanaan Pembangunan Nasional/ Badan Perencanaan Pembangunan Nasional (BAPPENAS), Strategi Nasional Akses terhadap Keadilan, (Jakarta: Bappenas, 2009), hlm. 52.

30 Ibid.

31 Uli Parulian Sihombing (ed.) et. al., Mengelola Legal Clinic, Panduan Membentuk dan Mengembangkan Kampus Untuk Memperkuat Akses Keadilan (Jakarta: ILRC, 2009).
} 
kurang mampu untuk memanfaatkan jasa penasihat hukum atau advokat profesional.

LBH PTN sebagai pemberi Bantuan Hukum memberikan jasa hukum secara cuma-cuma kepada kelompok orang miskin sesuai dengan ketentuan UU Bantuan Hukum, apalagi di dalam pasal 1 angka 10 Rancangan Kitab Undangundang Hukum Acara Pidana memperluas definisi penasehat hukum tidak hanya terbatas pada advokat namun juga orang lain yang memberi jasa hukum baik di dalam maupun di luar pengadilan yang memenuhi persyaratan berdasarkan ketentuan Undang-undang. ${ }^{32}$

Dalam melaksanakan pemberian bantuan hukum berbasis access to justice, LBH PTN memiliki beberapa hak untuk menunjang kinerjanya, hal dapat kita lihat dalam Pasal 9 UU Bantuan Hukum, dimana LBH dapat:

a. melakukan rekrutmen terhadap advokat, paralegal, dosen, dan mahasiswa fakultas hukum;

b. melakukan pelayanan Bantuan Hukum;

c. menyelenggarakan penyuluhan hukum, konsultasi hukum, dan program kegiatan lain yang berkaitan dengan penyelenggaraan Bantuan Hukum;

d. menerima anggaran dari negara untuk melaksanakan Bantuan Hukum berdasarkan Undang-Undang ini;

e. mengeluarkan pendapat atau pernyataan dalam membela perkara yang menjadi tanggung jawabnya di dalam sidang pengadilan sesuai dengan ketentuan peraturan perundang-undangan; f. mendapatkan informasi dan data lain dari pemerintah ataupun instansi lain, untuk kepentingan pembelaan perkara; dan

g. mendapatkan jaminan perlindungan hukum, keamanan, dan keselamatan selama menjalankan pemberian Bantuan Hukum.

Ketentuan pasal tersebut secara jelas menyatakan bahwa LBH PTN dapat memperkerjakan advokat, paralegal, ${ }^{33}$ dosen, dan mahasiswa fakultas hukum. Advokat yang memilki ijin praktik direkrut bersamasama dengan dosen, paralegal dan mahasiswa fakultas hukum untuk memberikan pelayanan bantuan hukum berupa penyuluhan hukum, konsultasi hukum, dan program kegiatan lain yang berkaitan dengan penyelenggaraan Bantuan Hukum dengan bantuan pendanaan dari negara.

Selain itu dalam melaksanakan fungsinya LBH PTN memiliki hak untuk mengeluarkan pendapat atau pernyataan dalam membela perkara yang menjadi tanggung jawabnya di dalam sidang pengadilan, mendapatkan informasi dan data lain dari pemerintah ataupun instansi lain, untuk kepentingan pembelaan perkara; dan mendapatkan jaminan perlindungan hukum, keamanan, dankeselamatanselamamenjalankan pemberian Bantuan Hukum. Termasuk jaminan perlindungan hukum yang diperoleh oleh LBH PTN adalah tidak dapat dituntut secara perdata maupun pidana dalam memberikan Bantuan Hukum yang menjadi tanggung jawabnya yang dilakukan dengan iktikad baik di dalam maupun di luar sidang pengadilan sesuai Standar Bantuan

${ }^{32}$ Berdasarkan RUU KUHAP yang diterima penulis pada tanggal 14 Maret 2012 dalam acara public hearing RUU KUHAP oleh Komisi III DPR RI di Universitas Airlangga Surabaya.

33 Andik Hardijanto mendefinisikan paralegal sebagai seorang yang bukan sarjana hukum tetapi mempunyai pengetahuan dan pemahaman dasar tentang hukum dan hak asasi manusia, memiliki keterampilan yang memadai, serta mempunyai kemampuan dan kemauan mendayagunakan pengetahuan dan pengetahuannya itu untuk memfasilitasi ikhtiar perwujudan hak-hak asasi masyarakat miskin/komunitasnya. Tim The Indonesian Legal Resource Center dan Forum Solidaritas LKBH Kampus, Op.Cit., hlm. 28. 
Hukum berdasarkan peraturan perundangundangan dan/atau Kode Etik. ${ }^{34}$

Secara semiotik, pengaturan teks dalam pasal UU Bantuan Hukum sebagaimana dikemukakan di atas dapat dimaknai bahwa secara kontekstual pemberian pelayanan bantuan hukum yang dilakukan oleh LBH PTN berbeda dengan pelayanan jasa hukum yang dilaksanakan oleh Advokat. Advokat dalam memberikan pelayanan jasa hukum memiliki hak untuk menerima honorarium, sedangkan LBH PTN sebagai pemberi bantuan hukum dilarang menerima pembayaran dari dari Penerima Bantuan Hukum dan/atau pihak lain yang terkait dengan perkara yang sedang ditangani Pemberi Bantuan Hukum. ${ }^{35}$ Bahkan terdapat ancaman pidana bagi pemberi bantuan hukum yang terbukti menerima atau meminta pembayaran dari Penerima Bantuan Hukum dan/atau pihak lain yang terkait dengan perkara yang sedang ditangani berupa pidana penjara paling lama 1 (satu) tahun atau denda paling banyak Rp50.000.000,00 (lima puluh juta rupiah). ${ }^{36}$ Ketentuan pemidanaan dalam pasal ini dapat dimaknai sebagai sarana kontrol untuk mengembalikan arah bantuan hukum yang pro masyarakat miskin dan bukan dijadikan sarana untuk menenggak keuntungan profit dengan dalih pemberian bantuan hukum bagi masyarakat.

Perdebatan mengenai kebolehan dosen PNS yang tergabung dalam LBH PTN dalam proses peradilan sebagai pemberi bantuan hukum menjadi jelas dengan ketentuan ini. Dosen PNS dapat beracara di proses peradilan sepanjang posisi dosen PNS sebagai bagian dari LBH PTN yang hanya melakukan pengabdian masyarakat dan pengembangan keilmuan sebagai pemberi bantuan hukum, terbatas pada perkara yang melibatkan orang tidak mampu dan mereka dilarang menerima atau meminta pembayaran dalam bentuk apapun dari penerima bantuan hukum.

Implementasi jaminan access to justice dalam pemberian bantuan hukum, selain dilakukan dengan cara-cara yang disebutkan di atas dapat juga dilakukan penguatan dalam bentuk pengembangan keparalegalan dan pengembangan pendidikan hukum yang menopang implementasi bantuan hukum. Dua hal ini dapat dengan mudah dilakukan oleh LBH yang tergabung di Perguruan Tinggi karena memiliki sumber daya yang cukup baik.

Pengembangan keparalegalan menjadi penting disaat situasi keterbatasan atas akses geografis, pengetahuan dan keterampilan hukum di masyarakat. Harapannya dengan melakukan pengembangan keparalegalan, produk paralegal yang dihasilkan dapat memainkan peranan penting berupa melakukan pendidikan hukum di masyarakat, pendampingan penanganan kasus-baik lewat mekanisme formal maupun nonformal, fasilitator advokasi, mediasi serta fungsi lain yang pada prinsipnya menjembatani warga masyarakat miskin dan terpinggirkan dengan jaringan bantuan hukum dan advokasi di tingkat lokal bahkan tingkat nasional. Pengembangan pendidikan hukum yang menopang implementasi bantuan hukum juga menjadi penting untuk menyediakan sumber daya para sarjana dibidang hukum yang juga mempunyai paradigma pengetahuan

34 Pasal 11 UU Bantuan Hukum.

35 Pasal 20 UU Bantuan Hukum.

36 Pasal 21 UU Bantuan Hukum. 
yang berperspektif hak asasi manusia dan menggunakan keahliannya itu untuk bersamasama terlibat dalam gerakan bantuan hukum. LBH PTN dapat mengembangkan isu ini sebagai salah satu mata kuliah yang diajarkan di perguruan tinggi mereka. ${ }^{37}$

Dengan demikian, Lembaga Bantuan Hukum Perguruan Tinggi Negeri dapat kembali berperan melaksanakan Tri Dharma Perguruan Tinggi berupa pengabdian kepada masyarakat yang menjamin access to justice secara lebih optimal pasca diberlakukannya UU Bantuan hukum dalam bentuk pendampingan masyarakat miskin dalam proses peradilan dan penguatan kelompok masyarakat melalui program-program penyuluhan hukum.

\section{E. Penutup}

\section{Kesimpulan}

UU Bantuan Hukum mereposisi peran pengabdian masyarakat Lembaga Bantuan Hukum Perguruan Tinggi Negeri setelah vacuum akibat tidak adanya aturan yang jelas dan tegas yang mengakomodir peran mereka selama puluhan tahun bergerak di bidang bantuan hukum pro masyarakat miskin. Perluasan definisi Pemberi Bantuan Hukum dalam UU Bantuan Hukum dalam Pasal 1 ayat (3) jo Pasal 8 ayat (2) UU Bantuan Hukum meberikan peluang bagi para dosen PTN, paralegal dana mahasiswa hukum yang tergabung dalam LBH untuk melakukan pengabdian masyarakat sekaligus pengembangan keilmuan hukum.

Implementasi jaminan access to justice yang dilakukan LBH PTN dapat dilakukan secara lebih optimal pasca diberlakukannya UU Bantuan Hukum. Proses pemberian pelayanan bantuan hukum dapat dilakukan dengan cara melakukan pendampingan secara litigasi maupun non litigasi, penyuluhan hukum, konsultasi hukum, dan program kegiatan lain yang berkaitan dengan penyelenggaraan Bantuan Hukum dengan bantuan pendanaan dari negara. Selain pengembangan keparalegalan dan pengembangan pendidikan hukum dapat dilakukan dengan tujuan akhir penguatan jaminan acces to justice kepada seluruh masyarakat dengan tanpa memandang strata sosial tertentu.

\section{Saran}

Pengaturan peraturan pelaksanaan dan teknis terkait UU Bantuan Hukum penting untuk segera dirancang dan disahkan, mengingat masih multi interpretatifnya banyak ketentuan pasal yang mengatur pemberian bantuan hukum dalam UU Bantuan Hukum. Hal ini perlu menjadi perhatian agar tidak terjadi miss konsepsi dalam pelaksanaan teknis di lapangan yang berimbas tidak tercapainya menjamin access to justice yang menjadi substansi tujuan dibentuknya UU Bantuan Hukum.

Pemahaman yang sama di antara para penegak hukum dalam memposisikan LBH Kampus sebagai Pemberi Bantuan Hukum sebagaimana diatur dalam UU Bantuan Hukum menjadi penting agar implementasi jaminan access to justice yang dilakukan LBH baik PTN maupun PTS dapat lebih optimal. Hal ini dapat dilakukan melalui forum MAHKEJAPOL yang terdiri dari unsur Kehakiman, Kejaksaan dan Kepolisian bersama dengan Kementerian Hukum dan HAM dan Kementerian Pendidikan dan Kebudayaan dalam mendorong arah pengabdian masyarakat yang berbasis access to justice.

Kelompok Kerja Akses terhadap Keadilan Kementerian Negara Perencanaan Pembangunan Nasional/ Badan Perencanaan Pembangunan Nasional (BAPPENAS). Op.Cit., hlm. 57. 


\section{DAFTAR PUSTAKA}

\section{Buku}

Ismanu, Imam, et. all., Profil Pengabdian Masyarakat BKBH FH UB 2012 (Malang: BKBH FH UB, 2013).

Ibrahim, Johnny, Teori dan Metodologi Penelitian Hukum Normatif, (Malang: Bayumedia Publishing, 2005).

Marzuki, Peter Mahmud, Penelitian Hukum (Jakarta: Kencana, 2007).

Irianto, Sulistyowati, Memperkenalkan kajian Sosio Legal dan Implikasi Metodologisnya (Jakarta: Pustaka Larasan, 2012).

Sihombing, Uli Parulian (ed.), et all, Mengelola Legal Clinic, Panduan Membentuk dan Mengembangkan Kampus Untuk Memperkuat Akses Keadilan (Jakarta: ILRC, 2009).

\section{Makalah / Artikel / Prosiding / Hasil Penelitian}

Aminah, Siti, Hak Bantuan Hukum Dalam Berbagai Konteks Analisa Terhadap UU No.16 Tahun 2011 Tentang Bantuan Hukum (makalah).

KelompokKerjaAksesterhadapKeadilanKementerian Negara Perencanaan Pembangunan Nasional/ Badan Perencanaan Pembangunan Nasional (BAPPENAS), Strategi Nasional Akses terhadap Keadilan, (Jakarta: Bappenas, Mei 2009).

Mochtar, M. Akil, "Bantuan Hukum Sebagai Hak Konstitusional Warga Negara" (makalah disampaikan pada Karya Latihan Bantuan Hukum (KALABAHU), diselenggarakan oleh Lembaga Bantuan Hukum, Jakarta, 30 Maret 2009).

Tim The Indonesian Legal Resource Center dan Forum Solidaritas LKBH Kampus, Menjamin Hak Atas Bantuan Hukum Bagi Masyarakat Marginal Position Paper RUU Bantuan Hukum dan Peran LKBH Kampus, (Jakarta: Delapan Cahaya Indonesia Printing, 2010).

\section{Internet}

"Dipertanyakan, Dedikasi Pengacara Sukses untuk Probono", http://www.hukumonline.com/ berita/baca/It4fa399b190322/dipertanyakan-dedikasi-pengacara-sukses-untuk-probono.

"Bantuan Hukum: Akses Masyarakat Marjinal terhadap Keadilan", http://www.bantuanhukum. or.id/index.php/id/dokumentasi/ penerbitan/231-bantuan-hukum-aksesmasyarakat-marjinal-terhadap-keadilan.

\section{Peraturan}

Undang-Undang Dasar Negara Republik Indonesia Tahun 1945

Undang-Undang Nomor 8 Tahun 1981 tentang Hukum Acara Pidana.

Undang-Undang Nomor 8 Tahun 1974 tentang Pokok-Pokok Kepegawaian.

Undang-Undang Nomor 43 Tahun 1999 tentang Perubahan Atas UU No. 8 Tahun 1974 tentang Pokok-Pokok Kepegawaian.

Undang-Undang Nomor 18 Tahun 2003 tentang Advokat.

Undang-Undang Nomor 30 Tahun 2004 tentang Jabatan Notaris.

Undang-Undang Nomor 14 Tahun 2005 tentang Guru dan Dosen.

Undang-Undang Nomor 16 Tahun 2011 tentang Bantuan Hukum.

Undang-Undang Nomor 12 Tahun 2012 tentang Pendidikan Tinggi.

Peraturan Pemerintah Nomor 53 Tahun 2010 tentang Disiplin Pegawai Negeri Sipil.

Putusan Mahkamah Konstitusi No.06/PUU-II/2004 tanggal 31 Desember 2004.

Universal Declaration of Human Rights (UDHR).

International Covenant on Civil and Political Rights (ICCPR). 